\title{
Role Of Street Vending In Urban Livelihood (In Case Of Mettu Town)
}

\author{
https://doi.org/10.21272/sec.4(1).82-101.2020
}

\section{S.N. Singh, ORCID ID: https://orcid.org/0000-0002-1494-44890000}

Dr, Associate Professor of Economics and Law in the Department of Economics, Faculty of Business and Economics, Mettu University, Ethiopia

\begin{abstract}
The informal economy plays a key role in ensuring economic growth and social well-being in developing countries. In particular, in Africa, more than $60 \%$ of the urban population, as well as almost $80 \%$ of the nonagricultural population, are employed in the informal economy. The main purpose of the study is to study the role of street commerce in supporting urban life. The object of study is one of Ethiopia's remote cities, Matt. The extent of the impact of street commerce on the incomes of the urban population, including those who do not own land, is analyzed in the study. The study is aimed at finding patterns between the living conditions of urban population living on the brink of poverty and the dynamics of street commerce, the proceeds of which are directed to meet their daily physiological needs. The scientific approaches to the study of the relationship between the volume of street commerce and living conditions of urban population have been systematized. The source of the primary data for the survey is questionnaires that contained information on the sociodemographic profile of street traders, the extent of their activity, the amount of start-up capital, access to credit, and their main difficulties in this type of activity. Descriptive statistics methods became a methodological tool of the conducted research. The results of the empirical analysis have shown that there is a positive correlation between street commerce and the well-being of urban populations. In addition, it is found that about $37.9 \%$ of people involved in street trading are experiencing problems as a result of tightening regulatory regulations by the state. The study empirically confirms and theoretically proves that street selling is one of the important sources of urban existence in Ethiopia. The results of the study can be useful for government officials, NGOs, international institutions, as well as researchers dealing with this issue.
\end{abstract}

Keywords: street trade, livelihoods, urban poverty, alternative employment opportunities.

JEL Classification: J46, O17.

Cite as: Singh, S.N. (2020). Role Of Street Vending In Urban Livelihood (In Case Of Mettu Town). SocioEconomic Challenges, 4(1), 82-101. https://doi.org/10.21272/sec.4(1). 82-101.2020.

(C) The Author, 2020. This article is published with open access at Sumy State University.

\subsection{Introduction}

The informal economy has experienced rapid growth in developing countries and has consequently attracted increasing attention among academics, researchers, social development activists, and policy makers. If there is a proper documentation of contribution of informal sector in the socio economic development that includes income and education status of those indulging in informal sectors bring attentions for the policy makers to focus on the specific business points that are being experienced at present by the people involved in informal sector. It is believed that the rapid growth of this sector has been influenced by increasing unemployment in developing countries. According to International labour organization (ILO 2004), the lack of jobs in the formal sector of the economy as well as the lack of skills in a large part of the labour force has resulted in the growth of a substantial informal sector in which most workers are in low paid employment under unregulated and poor working conditions. Informal sector encompasses largely unrecognizable, unrecorded and unregulated small scale activities including; small enterprises, household enterprises, self employed sectors such as street vendors, cleaners, shoe shiners etc. with the lack of governmental regulations or lack of institutions that provide job security and benefits, this sector compromises the largest part of economies of developing countries (Suharto, 2015). 
Informal sector was a large number of small scale production and services activities that are individual or family owned and labour intensive, informal sector does not fall under the purview of organized economic activities. Most workers entering this sector are recent migrants unable to find employment in the formal sector and their motivation is usually to obtain sufficient income to survive, relying on their own indigenous resources to create work (Singh, 2014). As many members of the household as possible, including women and children, are involved in income generating activities, and they often work very long hours. It is difficult to estimate the exact magnitudes the informal sector but there is general agreement that the informal sector comprises a growing proposition of economic activity. Particularly in less developed countries 50\% of the labor force engaged in the informal economy (Budd, 2010). At the same time, it should be noted that in both developed and developing countries, the informal sector is connected to the formal sector of the national and global economy through subcontracting networks and commodities chains. Statistics on the informal economy are unreliable by virtue of the subject, yet they can provide a tentative picture of its relevance; for example, informal employment makes up $48 \%$ of non agricultural employment in North Africa, $51 \%$ in Latin America, $65 \%$ in Asia and $72 \%$ in sub-Sahara Africa. If agricultural employment is included, the percentages raise, in some countries like India and many subs - Sahara African countries beyond $90 \%$. Estimates for developed countries are around $15 \%$. In developing countries, the largest part of informal work around $70 \%$ is selfemployed, wage employment predominates.

The majority of informal economy workers are women. Policies and development affecting informal economy have thus a distinctly gendered effect (Benjamin, 2010).Street vendors are a large and very visible work force in cities, yet it is difficult to accurately to estimate their numbers. Official statistics are available for some countries. Though they may underestimate the population engaged in street vending. The National policy for urban street vendors, 2004 defined a street vending as a person who offers goods and services for sale to the public without having permanently built up structure but with a temporary static structure or mobile stall. Street vendors may be stationary by occupying space on the pavement or other public / private areas, or may be mobile sense that the move from place to place carrying their wares on push carts or in cycles or baskets on their heads, or could sell their wares in moving train, bus. The street vendors many refer to vendors with fixed stall, such as kiosks, vendors who operate from semi fixed stalls like folding table, creates, collapse stands, wheeled push carts that are removed from the street vending and stored over night, vendors who sell from fixed locations without a tall structure, displaying merchandise on clothes or plastic sheet, or mobile vendors who walk or paddle their bicycle through the streets as they sell (ILO, 2010). Informal sector a tool for eradication analysis that the improvement definition and the problem of informal sector. In developing countries like India, where the pressure of population is overall on the increase, the development of the informal sector can go a long way in employment generation and consequent eradication of poverty. The author put forth a few suggestions for promoting this sector. The sector needs strong support from the government in terms of product promotion programmers, entrepreneurial development, subsides and incentives, (Vashit 2013). Small Enterprises Development Agency (SEDA, 2008) in its on informal street trading policy framework for metropolitan and local municipal brought to light the constraints that negatively impacted street traders in South Africa. The main challenges faced by them where lack of access financial services such as credit and saving, limited access to training and improper linkages and improper suppliers form formal business. The municipal challenges in dealing street traders were also found. It revealed that instability in informal trader's representation and association, proliferation among informal trading organization in the form of fight for reorganization support and power where the major problems them they had to face with regarded to street vendors. Organization and unorganized labor organizing unorganized workers point out that over $90 \%$ by 2011 of the work force lack the power of organization. The unorganized sector constitutes $91.5 \%$ while the organized labour comprises $8.5 \%$ of the labour force. The author has also points out that $95.8 \%$ of the female labour force employed in the unorganized sectors; only $4.2 \%$ of the female force is employed in the organized sector. He examines various models in economic theory and their implications for unorganization. (Navid, 2012).

In Ethiopia, the situation is most severe as compared to other developing countries. The country has been experiencing a rapid urban growth rate during the past few decades. According to Central Statistical Authority (CSA, 2003), the countries urban population grew at a rate of $6.68 \%$ per annum between and 2000 and 2002. Similarly, the agglomeration index calculated urbanization at $3.7 \%$ between 2002 and 2004, and the percent of urban area doubled according to the agglomeration from 2004 to 2017 (Kediri, 2009). 
A more recent study of central statistical authority (CSA, 2004) reported that over 1 million urban informal employments in the county and this accounts for $48.3 \%$ of the economically active urban population inspire of large proportion of operators in the informal sector in general and street vending in particular, however much emphasis has not yet been given to this urban economic units. There was very little information available about the status and role of street vendors played in economic development and serve delivery in Ethiopia as well assign Mettu Town. This due to the absence of conducting researchers works on street vending problems and to some extent the lack of aggregate data. Street vendor's urban poor and economic potential discussed the roots of street vending phenomenon and suggested several street vending management solutions from best practices folded around the world. It revealed that street vendors where a big challenge for urban management. The city managers eliminated them as they defaced city sight. Repressive municipal policies towards street vendors with the development of the policy have been a counterproductive. Formation of a good policy like Applying "trickle down effect "in street vending allocating scarce capital in the cities to alleviate poverty micro financing registration process of small business would make street vendors contribute productivity to the society (Harlan Dimas, 2008). Operator which makes it impossible to estimate the share of street vendor in the informal sector in the area under investigation and it seems the informal sector is an important player in the creation of employment opportunities particularly in urban areas. Individual initiatives and credible strategy about this sector are required to reduce poverty in the study area particularly as well as for the country. This study is therefore intended to investigate the contribution of street vending to socioeconomic development in Mettu town at small scale.

\subsection{Statement of the problem}

The informal sector economic activities were rapidly expanding globally, especially in developing countries. In Africa for instance, Informal sector activities accounted for almost $80 \%$ of non agricultural employment, over $60 \%$ of urban employment and over $90 \%$ of new jobs for approximately the past decades (Manganga 2009). It was also pointed out that the informal economy can no longer be considered a temporary phenomenon, neither in Africa nor in other parts of the world. Moreover, it serves as a safety net for the disadvantage people in developing countries. People, who could not get credit, could not be absorbed by the formal sector due to lack adequate skills, become increasingly engage in it. It's a very essential activity for the survival of people in cities who could not carry through their needs through formal sector. Thus, it has become a shield for the disadvantaged people of many of the developing countries larger cities (Losby et al., 2008).

Although there were less privileged people or disadvantaged such as poor women, migrants, children, youths or people who have no chance of getting a job in the street vending sub sector, some studies such as the study of (Manganga 2009) and (Mitullah, 2007) tried to demonstrate that the sector is not only a place where a poor and marginalized are to be found. But, the pointed out that, there are people economically better of that are operating in the sector. Moreover, it serves are safety net for the disadvantaged people in developing countries. People, who could not get credit, could not be absorbed by the formal sector lack of adequate skills, become increasingly engage in it. It is a very important activity for the survival of people in cities who could not accomplish their needs through informal sector to the society, and it specifically widens our understanding of the nature of street vending activity in Mettu town.

In the absence of basic information about the problem associated of street vendors the policy makers and development practitioners have given more efforts on development of formal sector. However, the growth and development of Informal Sector is required to reduce poverty for unskilled labour in urban areas like Mettu. It is observed that there are no studies have been conducted on the same problem in the research area and therefore this study is important to fill up the gap and also add some literature.

\subsection{Research Questions:}

These were the following questions related to the problem of street vendor in the Town and researcher was intended to find out the correct answers on the same issues.

1. What were the approximately number of street vendors in Town and their vending activities?

2. What were the challenges faced by the street vendors while set up the business?

3 . What were the socioeconomic contributions provided by street vending?

4. What were the factors lead to street vending to join side walk occupation in Mettu town? 


\subsection{Objectives of the study}

\subsubsection{General objective}

The general objective of this study was to assess the status of street vendors and their role in supporting urbanlivelihood in Mettu Town.

\subsubsection{Specific objectives}

To examine the business activities were being run by the street vendors in the Town.

To identify the challenges faced by street vendors

To examine socioeconomic contributions provided by street vending.

To examine the driving factors that leads street vending to join side walk occupation.

\subsection{Significance of the study}

The finding of this study would be important because it will provide information on the issues of linkages between informal sector and economic development in the country. This might helpful for Policy makers as well as development practitioners at the moment to design the strategies of development policies for informal sectors. The results of the study will provide the pace for other researcher as a guideline on the same issue and finally it helps to forward policy recommendations about the importance of informal sectors for generating employment opportunities for unskilled labor and supporting livelihoods based on the findings. Overall the society of the country will be benefited from the outcome of research in manifolds.

\subsection{Scope of the study}

The feasible study on the informal sector will provide wide scope for the unskilled labors to get employment opportunities in this sector. The scope of this study would be geographically to Mettu Town Addition the study to assessing socioeconomic effects of street vending in urban livelihood in Mettu Town in order to manageable study. This thesis will mainly concentrate on cause and effect of street vendors in Mettu Town. However, it does not look over all informal sector rather than it only use street vending analysis to investigate proposes.

\subsection{Limitation of the study}

This study would be geographically limited to Mettu Town and during preparation of research paper the researcher is faced many challenges such as unwillingness of some street vendors to participate and responding correct information about their business activities due to fear and to some extent prevailing illiteracy among them. Other general constraints are finance, time and the shortage of reference materials on the related issues. Despite these obstacles the researcher has attempted his level best to prepare research for conducting research on problems encountered by the informal sector in the country.

\subsection{Organization of the study}

This study was organized into five chapters and in order the first chapter has focused on introduction of the study including background, statement of the problem, objectives, scope and the limitation of the study. The second chapter covered the literature review theoretically and empirically explaining the studies carried out on the same problem of street vending and informal sector not only in the country but also across the world particularly developing countries. The third chapter deals with the data source, sample size and methodology of the study. The fourth chapter was about data analysis and discussion based on finding while, the fifth chapter contains conclusion and recommendation from finding of data analysis discussion.

\section{Literature review}

\subsection{Theoretical Literature Review}

\subsubsection{Definitions and Concepts of Informal Sector}

Informal Sector was "sector which encompasses all jobs which used to refer to only illegal activities, such as individual earn wags but not does not which are not recognized as normal income sources which tax are not paid. The term is something them on his or her income tax, or a cruel also be inter pretend to include legal activity such as jobs that are performed in exchange for something other than money oppose of formal sector".hhp//ww .business dictionary .Com definition informal sector htm. 
The informal sector or informal economy refers to and income that are partially or fully outside government regulation, taxation, and observation. The main attraction of the undeclared economy is financial. The activity allow employers, paid employee and the self-employed to increase their take home earnings or reduce their costs by escaping taxation and social contribution. It means of employment who cannot find job in the formal sector. But, a loss in budget revenues by reducing taxes. Http;//web. World bank.org.

Informal sector was the existence of unorganized, unregulated and mostly legally that is unregistered. The informal sector was recognized in 1970s, following observations in several developing countries that massive additions to the urban labor force failed to show up informal modern sector employment statistics. The bulk of new entrants to the urban labor force seemed to their own employment or to work for small-scale family owned enterprises (Todaro, 1994).

The self-employed were engaged in a remarkable array of activities ranging from hawking, street vending, letter writing , knife sharpening, and junk collecting to selling fireworks, prostitution, drug pledging, sconce charming, others found jobs are mechanics, carpenters, small artisans, barbers and personal servants still others were highly successful small-scale entrepreneurs which several employees (mostly relative) and higher income. The informal sector continues to play an important role in developing countries, despite decades of begin neglected at best and outright hostility at worst. In many developing countries, about half of the employed urban population works in the informal sector (Todaro, 1994).

Street vendors could be stationary and occupy space on the payment or other public /private areas or could be mobile ,and move from place carrying their wares on push carts or in cycles or baskets on their heads ,or could sell their wares in moving house . The government of India has used the term "urban vendor "as inclusive of both traders and services providers, stationary as well as mobile and incorporates all other local /region specific term used describe them, such as hawker, pherilualla, Rehi- patriulalla foot path dekandeks, sidewalk traders and more definition as include in the national policy on urban street vendors (2004) Department of Urban Employment and Poverty Alleviation, (DUEPA).

\subsubsection{Approaches to Define Informal Sector Enter prices}

\section{A. Micro Enter price Approach}

Informal sector defined through different approaches. The most common measures is the number of worker and capital investment. Many studies focused on enterprise with up five to ten or sometimes twenty workers. According to perspective approach, an enterprise can be interpreted as belonging to the lower end of the urban economic development.

\section{B. Working Poor Approach}

The informal sector is also defined as an activity of lower income population such as poor households, poor individuals and so on. Hence, it is thought to earn an income below the regular minimum wage (Haans, 1989)

\section{The legality Approach}

The proponents have tried to define the informal enterprises in terms of registration, payment to taxes and other institutional regulations and requirements. According to proponents, the informal sectors are those enterprises that are not officially registered, that do not have required license, taxes and finally that do not fulfill a host of other institutional regulation and requirements that are legally binding on producers and traders (Todaro, 1976).

\section{The Labor Market Approach}

The labor market definition of informal sector approach is segmenting or not directly linking the informal sector to the formal sector. This perspective divides the urban labor market into formal and informal dichotomy and the sector is defined to include workers outside the formal economy (Haans, 1989).

\subsubsection{History of Study of the Informal Economy}

Under definition sub-title above we have seen how various economists define informal economy. Here we will also see the history of the study close to its definitions. The concept of informal sector was first coined in an international labor organization, the study of the urban market Ghana (ILO, 1973). It will be subsequently 
used in international labor organization, organization report of labor market by the world bank in series of urbanization and poverty through the third world (Sethuraman, 1981).

Informal sector/employment was comprised of both self -employment in informal enterprises (i.e. small and or unregistered) and wage employment in informal jobs (i.e. without secure contracts worker benefits, or social protection). In all developing countries, self-employment comprises a greater share of urban informal employment than wage employment.

Self-employment represents nearly one-third of total urban employment worldwide, developed countries $12 \%$ of total urban employment than developing countries (i.e., 53\% of urban employment in Sub-Saharan Africa, 44\% in Latin America, 32\% in Asia, and 31\% in North Africa) to urban employment is counted approx 12\% in LDCs and 53\% developing countries. Informal wage employment is also significant in the developing countries of world. It comprises $34 \%$ to $40 \%$ informal employment in urban informal sector. Informal wage employment is comprised of employees of informal enterprises as well as varies types of informal wage workers, work for continue enterprise, household's, or who have no fixed employment.

\subsubsection{Characteristics of Informal Economy}

\section{A. Legal versus Illegal}

Economic activities can be distinguished by the manner in which goods and services are produced for exchanged. Legal income generated from the activities that are legal for portion of activities that produces legally sourced income; the appropriate reporting requirements to taxing or regulatory authority may not be fulfilled. Though, under reported, or concealed, this activity produces goods and services whose sell or exchange is not prohibited.(for example, Illegal income was generated from illegal activities that are winning from illegal sampling, earning from illegal prostitution, smuggling illegal trade drugs, tobacco, fire armies and alcohol skimming of receipts to sharking theft and other activities and specially banned by law.

\section{B. Cash as most medium of exchange}

Another key aspect of the informal economy was the cash which is most important commonly exchanged between parties rather than check payroll statement or credit card. The purpose of using of currency rather than bank credit, is avoid creating a record of activities (Smith, 1991).

\subsection{Empirical literature}

\subsubsection{Contribution of Informal Sector to Employment}

The World Bank (1991) indicates that informal sector employment is total labor force remained high between the year 1978 and 1988. It has observed about 92\% of the total employment. Similarly, international labor organization (1989) reported that informal sector employment has increased by an average of $0.7 \%$ each year between 1980-1988 in Africa and more employed people than the formal sector by creating 6 million new jobs against 0.5 million over the same period. The informal sector contributes to the major parts of employment then informal sector is seen to contribute at a lower rate, significantly in the term of income generation it provides between 20-30 rural incomes (Bagachwa, 1995).

\subsubsection{Contribution of the informal Sector to GDP}

National informal sector survey (1991) in Tanzania, argued that the contribution of informal sector to the growth domestic product in 1991(about 32\%). This is quite reasonable amount bearing in mind that this sector is not counted in the office statistics due to the exclusion of this information in the circulation of national income a gross under the statements of the level of per capital income of the population is inevitable for the counting expansion of the Gross Domestic Product.

\subsubsection{Contribution of informal sector to the improvement of social-economic welfare}

Part from the contribution of the informal sector to poverty reduction, Omar (2009) reported that the informal sector plays a vital role in improving people welfare. The emphasis was on the key contribution to the house hold economy. 


\subsubsection{Informal sector and government policy}

The policy environment created the gap between the formal and informal sector since the sector was not officially recognized. However, policies formulated for other areas such as the agriculture, industrial, labor, registration, economic and education had tremendous impact on the informal sector character mode of operation and growth. The informal sector activities have been regarded as illegal and thus arms of law were effective due to adequate capacity of enforcement on one hand and smaller informal sector on the other hand, above all the economy was doing well and jobs were available, later on the situation change for the worth.

In general, development policies together with some government regulation have affected the growth of the informal sector. For instance, the nationalization acts of 1967, part leadership code of 1967 and the Ujaman village act, all worked against not only the growth of the sector, but also worked towards discouraging individual initiatives and barred participation in private ventures for leadership (Bagachwa, 1993).

\subsubsection{Contribution of street vendors}

The Informal Economy Monitoring Study (IEMS) revealed ways in which street venders strengthen their communities. Most street vendors provide the main source of income for their households, bringing food to their families and paying school fees for their children. Many venders try to keep the street clean and safe for their customers and provide them with friendly personal service.

\subsubsection{Contribution of street vendor to urban economies}

Street vendors were an integral part of urban economies in the world, offering easy access to a wide range of goods and services in public spaces. They sell everything from fresh vegetables to prepared foods, from building materials to garments and crafts, from electronics to auto repairs to haircuts.

\subsubsection{Contribution of the Informal Sector to Poverty Reduction}

The income generation opportunities offered by the informal sector provides a very important source of likelihood for a large proportion of the population in urban and rural areas. This manifested by the larger number of people employed in this sector. There are some researches which already be done on street vending related to these topics. Example, Tekele Wogari (2016), would be focused on the contribution of informal sector, particularly on street vendors in case study of Nekemte town. But he did not show the problem of low capital as a factor to run would be business. The other study was done by Teshome Kebede, (2014) and it focuses on the contribution of street vending business activities for urban resident (low income level society). By the same fashion with Tekele, he did not also cover and focused on low capital as a factor that hindering the sector. Informal sector also plays a vital role in improving people welfare. The emphasis on the key contribution to the urban household's economy. In this fact, with not informal activities, the house hold would suffer economic hardship. The informal economy monitoring study (IEMS) revealed ways in which street vendors strengthen their communities. Most street vendors provide the main source of income for their house hold. Bringing food to their families and paying school fees for their children. The study was done by Gemechu Chala, (2015) on the topics in the case study of Ambo town also explained /identified the same role of street vending for urban economy. These informal workers have strong linkages to the formal economy. Over half of the IEMS sample said, the source the goods they sell from formal enterprises many customers work informal jobs. Many vendors try to keep the street clean and safe for their customers and provide them with friendly personal service. Street trade also adds vibrancy to urban live and many places are considered a corner stone of historical and cultural heritage.

Street vendors were an integral part of urban economies in the world that offering easy access to a wide range of goods and service in public space. They sell everything from fresh vegetable's to foods vending, from building materials to garments(cloths) a crafts, from electronics to auto repairs and haircuts. Generally, the previous researchers stated and identified the contribution of informal sector in general and street vendor in particular to poverty reduction, GDP, income generation employment, and socioeconomic welfare for the low income level of urban resident societies and factors affecting the activities of the business. But there were some factors that are not included in the previous researchers studies. Example, Tekele Wogari, 2016 and Gemechu Chala, 2015 did not include lack of capital and government restriction as a factors affecting the sector. Therefore, it was important that these factors must be given spaces is present research. 


\subsection{Methodology of the study}

\subsection{Description of the study area}

Mettu town in south west part of Ethiopia located in the Ilu ababor zone of Oromia Region, Southwest Addis Ababa. The average annual rainfall of Mettu town is $1701 \mathrm{~mm}$. The average annual temperature is $19.90 \mathrm{c}$, it is astronomical location is $831^{\prime} 11^{\prime \prime N o r t h ~ l a t i t u d e ~ a n d ~ 29057 ' 47 " ~ E a s t ~ l o n g i t u d e . ~ a n d ~ a n ~ e l e v a t i o n ~ b e t w e e n ~}$ 2515 and 2547 meters above sea level.

Mettu town was located 600 meters from Addis Ababa. The road passing through the Mettu town is the road from Addis Ababa to Gambela. It is bounded by Sombochekakebele in north, Dubana Hagalo kebele in east, Hariro Chari kebele in south, and Liban Kura kebele in west direction.

According to the 2015 National census total population of Mettu town in 53,906 of whom 26,437 were males and 27,469 were females. Among the populations residing in Mettu town, 47.55 are followers of orthodox, $26 \%$ are followers of protestant, $26 \%$ are followers of wakefena, and the remaining populations are other religious followers. The 1994 National census reported this town is total population of 11,113 of whom 4981 were males and 6,132 were females.

\subsection{Method of data collection}

\subsubsection{Primary data source}

Primary data was mainly to be used in this study. using well designed follow by interview to collection questionnaires were used to collect data from venders and local officials and to maintain accuracy in the research the secondary data on respective research subject would also which spaces. However, the secondary data would be access institutions. The questionnaires includes details of venders social-demographic profile, the economic activities the of venders operation and the nature of linkages exists in terms of initial capital, credit, wages, purchases, sales, and labor mobility in the other sector and major challenges that faced by venders.

\subsubsection{Secondary data sources}

Besides the primary data sources, secondary data from various secondary materials like as: - written documents, books, magazines, and journals where used in the analysis of the case study.

\subsubsection{Sampling size and sampling techniques}

The target population of the survey would be street venders of Mettu town. According to the information obtained from Mettu town the respect to trade and market development, there was no complete record of street vendors. For the purpose of this study the would be based on sample only from the street vending in Mettu town besides the street vending other aspect interviews for employed workers street vending. Street vending was classifying in to three Kebele. The total populations from all street vending are 1808. Out of this 119 are (01) Kebele, 119 of them are (02) Kebele and (03) kebele 1570 of them are three kebele. Street vending was found in the Mettu Town. However, according to the estimation of Mettu town trade and market development, there are street venders engaged in different vending activities. The selection of sample size is based on the formula developed by, Yamane (1967).

$\mathrm{n}=\mathrm{N} / 1+\mathrm{N}(\mathrm{e})^{2}$

Where;

$\mathrm{n}=$ sample size

$\mathrm{N}=$ population size

$\mathrm{e}=$ level of precision/error term

Then the sample size in this study is calculated as follows

$\mathrm{N}=\mathrm{N} / 1+\mathrm{N}(\mathrm{e})^{2}=1808 / 1+1808(0.1)^{2}=1808 / 1+1808(0.1)$

$=1808 / 1+18.08$

$=1808 / 19.08=95$ (Round) 
Accordingly, 95 respondents were selected from the total population of 1808 venders as representatives of a total population. Stratified random sampling procedure would be applied to get information from street vendors in the study Mettu town. In order to obtain reliable of data, researcher has increase sample size to 95 persons. So by using the stratified sampling formula these samples distribute among the most important Street Vending.

The stratified random sampling preferred was because the sampled size was heterogeneous nature. The respondents were randomly selected and approach for interview. Mettu town trade and market development officials were purposefully selected and interviewed, using structured economic activities interview to access the outlook governing bodies towards street vendors and their business.

\subsection{Method data analysis}

The data gathered was analyzed to get relevant and real information. Descriptive analysis was used in the analysis of the collected data. Accordingly, tables, graphs, figures, percentages of street venders' characteristics, resource use and capital requirement of street vending activities were employed.

\section{Data analysis and discussion}

\subsection{Introduction}

This chapter deals with the finding based on a data collected from the residents of Mettu town who actually participate in street vending activities. This study covers parameters demographic aspects, sex composition, marital status, numbers of venders' educational status, occupation besides their income from vending spending.

\subsection{Questionnaire analysis}

The questionnaires are analyzed based on the data collected from vendor respondents of Mettu town. The analysis involves the personal characteristics of the sample respondents, and personal observation of the researcher.

The vending activities are characterized as fruits and vegetables, GarmentsVnding (Clothes), Motor Service, Food Vending and Flowers Vending activities. The following section presents the demographic structures, socio economic characteristics of the respondents and problems facing vendors.

\subsubsection{Demographic profile of the respondents}

The demographic characteristics of the respondent's parameters such as sex, education, age, marital status, migration status and others. Table 1 below introduces the demographic characteristics of respondents.

Table 1. Sex of sample vendors and their activities

\begin{tabular}{|c|c|c|c|c|c|c|c|c|c|c|c|c|}
\hline \multirow[t]{2}{*}{ Sex } & \multicolumn{2}{|c|}{$\begin{array}{c}\text { Fruits \& } \\
\text { vegetables }\end{array}$} & \multicolumn{2}{|c|}{$\begin{array}{l}\text { Garment } \\
\text { vending }\end{array}$} & \multicolumn{2}{|c|}{ Motor services } & \multicolumn{2}{|c|}{ Food vending } & \multicolumn{2}{|c|}{$\begin{array}{l}\text { Flowers } \\
\text { vending }\end{array}$} & \multicolumn{2}{|c|}{ Total } \\
\hline & No & $\%$ & No & $\%$ & No & $\%$ & $\mathrm{No}$ & $\%$ & No & $\%$ & No & $\%$ \\
\hline Male & 20 & 95.2 & 13 & 81.25 & 25 & 100 & & 55.6 & 10 & 66.7 & 78 & 82.1 \\
\hline Female & 1 & 4.8 & 3 & 18.75 & - & - & 8 & 44.4 & 5 & 33.3 & 17 & 17.9 \\
\hline Total & 21 & 100 & 16 & 100 & 25 & 100 & 18 & 100 & 15 & 100 & 95 & 100 \\
\hline
\end{tabular}

Source: own survey; 2018.

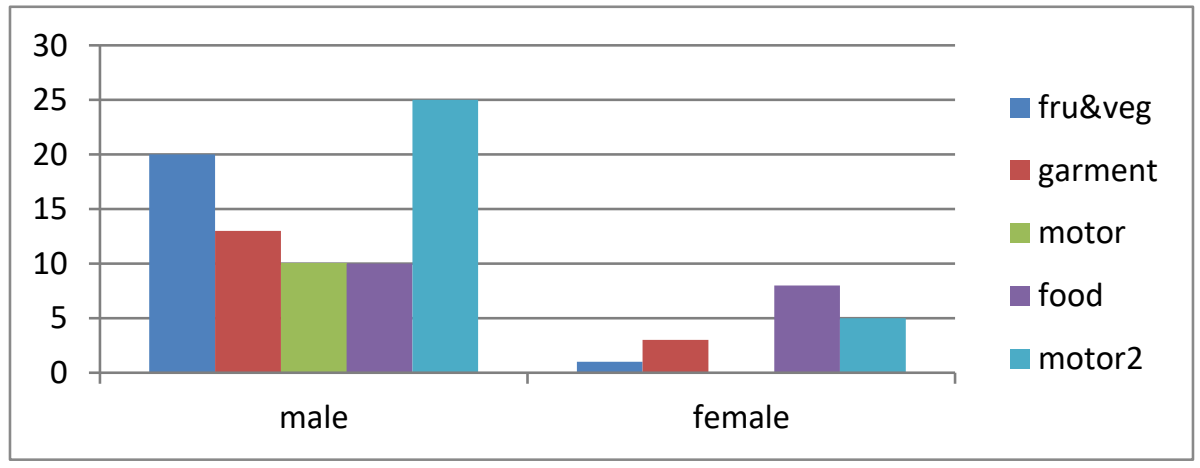

Figure 1. Sex of sample vendors and their activities

Source: own survey; 2018. 
Street Vending activity was particularly important source of employment and income for both gender groups. Male group represents the higher number compared to that of female groups. From the above table 4.1: about $82.1 \%$ of the enterprises were males and $17.9 \%$ were females. On the other hand, there are some interesting inter-firm variations with respect to enterprise owners. In Mettu, $95.2 \%$ of total enterprise owners in fruit and vegetables, and $17.9 \%$ food vending were females. Female number was also significant in flowers types of vendor activities such as selling of cosmetics, shoe vending and others. Such informal income generating activities gives women a special way to escape social and cultural restrictions strengthening their economic status in the households or outside.

The proportion of male entrepreneurs are however is the highest in the Motors service, Garments (clothes) and Flowers vending activities constituting $100 \%, 66.7 \%$ and $33.3 \%$ respectively. The owners were relatively youth who apart from family to sustain urban livelihood and students who support themselves to buy schooling stuffs based on the income generated from street vending source of income. This evidenced that urban employment have impotency, in case of Mettu town.

Table 2. Age structure of sample vendors and their activities

\begin{tabular}{|c|c|c|c|c|c|c|c|c|c|c|}
\hline \multirow[t]{2}{*}{$\begin{array}{c}\text { Age } \\
\text { structure }\end{array}$} & \multicolumn{2}{|c|}{$\begin{array}{c}\text { Fruits \& Vegetable } \\
\text { vending }\end{array}$} & \multicolumn{2}{|c|}{ Garments vending } & \multicolumn{2}{|c|}{ Motor services } & \multicolumn{2}{|c|}{ Food vending } & \multicolumn{2}{|c|}{ Flowers vending } \\
\hline & No & $\%$ & No & $\%$ & No & $\%$ & No & $\%$ & No & $\%$ \\
\hline$<17$ & 12 & 57.2 & 6 & 37.5 & 15 & 40 & - & - & 10 & 66.7 \\
\hline $18-40$ & 4 & 19 & 10 & 62.5 & 10 & 60 & 17 & 94.4 & 2 & 13.3 \\
\hline $41-50$ & 5 & 23.8 & - & - & - & - & 1 & 5.6 & 3 & 20 \\
\hline$>51$ & - & - & - & - & - & - & - & - & - & - \\
\hline Total & 21 & 100 & 16 & 100 & 25 & 100 & 18 & 100 & 15 & 100 \\
\hline
\end{tabular}

Source: own survey; 2018.

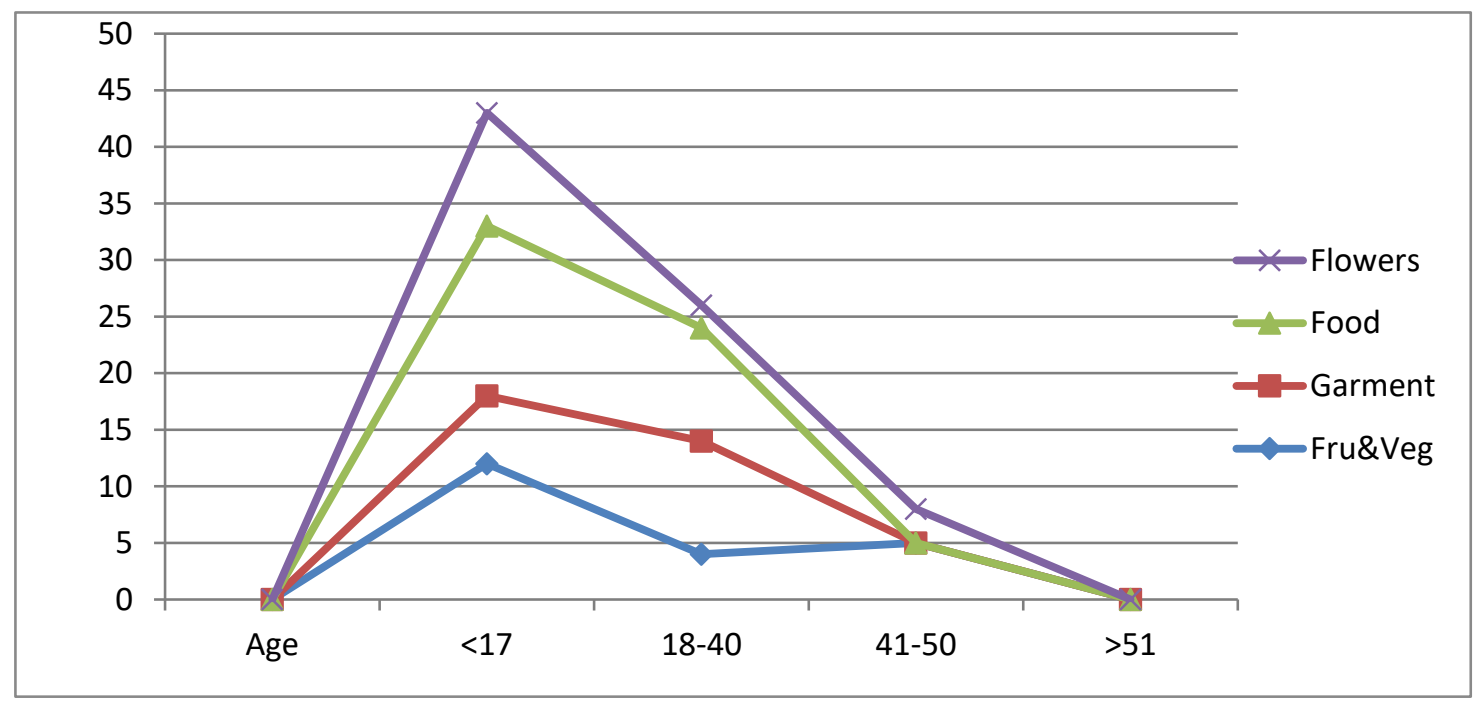

Figure 2. Age structure of sample vendors and their activities

Source: own survey; 2018.

As indicated in the above Table 2 vending operation was particularly important source of employment and income for youths. The informal sector in mettu town are highly diversified in nature. Vandors may get engaged in fixed location activities or mobile and semi mobile activities.

Although street vending was under taken by female and men of all age of 41-50 around have of vendors of Fruit and Vegetables 57.2\%, Garments (clothes) around 62.5\% and aged 41-50, with the proportion declining after aged 50 . The majority of respondents $45.3 \%$ were in youth age structure, i.e. between $18-40$ years. This age is the most economically active and innovative part of age structure whereas, the remaining $13.3 \%$ the vendors belongs to the age structure. 
Table 3. Marital status of sample vendors and their activities

\begin{tabular}{|c|c|c|c|c|c|c|c|c|c|c|c|c|}
\hline \multirow[t]{2}{*}{ Martial status } & \multicolumn{2}{|c|}{$\begin{array}{c}\text { Fruits \& } \\
\text { Vegetables }\end{array}$} & \multicolumn{2}{|c|}{$\begin{array}{c}\text { Garments } \\
\text { vending }\end{array}$} & \multicolumn{2}{|c|}{ Motor services } & \multicolumn{2}{|c|}{ Food vending } & \multicolumn{2}{|c|}{ Flowers vending } & \multicolumn{2}{|c|}{ Total } \\
\hline & No & $\%$ & $\mathrm{Nc}$ & $\%$ & No & $\%$ & No & $\%$ & No & $\%$ & No & $\%$ \\
\hline Single & 10 & 47.6 & 6 & 37.5 & 10 & 60 & 10 & 55.6 & 4 & 26.7 & 40 & 42.1 \\
\hline Married & 5 & 23.8 & 10 & 62.5 & 15 & 40 & 4 & 22.2 & 6 & 40 & 40 & 42.1 \\
\hline Divorced & 6 & 28.6 & - & - & - & - & - & - & 5 & 33.3 & 11 & 11.6 \\
\hline Widowed & - & - & - & - & - & - & 4 & 22.2 & - & - & 4 & 4.2 \\
\hline Total & 21 & 100 & 16 & 100 & 25 & 100 & 18 & 100 & 15 & 100 & 95 & 100 \\
\hline
\end{tabular}

Source: own survey; 2018.

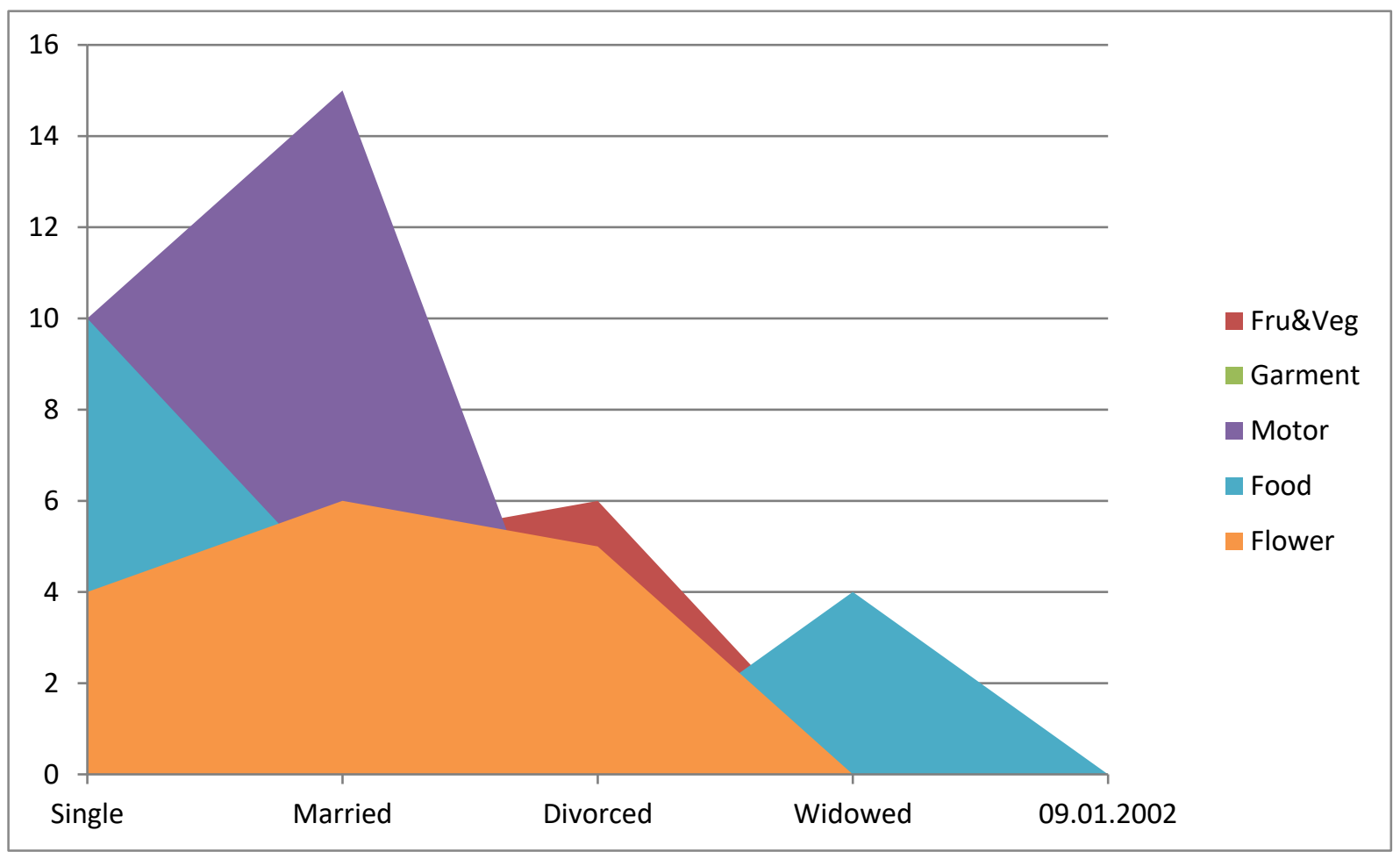

Figure 3. Marital status of sample vendors and their activities

Source: own survey; 2018.

On the other hand, the above table 4.3 : find out of that the majority of the respondents $42.1 \%$ are single, $42.1 \%$ are married, $11.6 \%$ divorced, and $4.2 \%$ are widowed. This evidence clearly indicates vending permits unmarried, married, divorced and widowed population to generate jobs and income with small capital outlay, and little skill in the survey area.

Street vending was a more important source of employment among married person than among unmarried and majority of them are only earning members. With respect martial proportion of vendors of the above mentioned product.

Table 4. Educational level of sample vendors and their activities

\begin{tabular}{|c|c|c|c|c|c|c|c|}
\hline \multirow[t]{2}{*}{$\begin{array}{l}\text { Education } \\
\text { level }\end{array}$} & $\begin{array}{c}\text { Fruit \& } \\
\text { Vegetables }\end{array}$ & $\begin{array}{c}\text { Garments } \\
\text { vending }\end{array}$ & $\begin{array}{c}\text { Motor } \\
\text { services }\end{array}$ & Food Vending & $\begin{array}{l}\text { Flowers } \\
\text { Vending }\end{array}$ & \multicolumn{2}{|c|}{ Total } \\
\hline & No & No $\%$ & No $\%$ & No & No $\%$ & No & $\%$ \\
\hline Illiterate & $\begin{array}{ll}7 & 33.3 \\
\end{array}$ & 25 & $10 \quad 40$ & 38.8 & 40 & 34 & 35.8 \\
\hline Primary & 28.6 & $\begin{array}{ll}3 & 18.75 \\
\end{array}$ & $\begin{array}{ll}15 & 60 \\
\end{array}$ & 11.2 & 26.7 & 30 & 31.6 \\
\hline Secondary & 14.3 & $\begin{array}{ll}2 & 12.5 \\
\end{array}$ & - & 22.2 & 13.3 & 11 & 11.6 \\
\hline $\begin{array}{c}\text { Technical \& } \\
\text { Vocational }\end{array}$ & 23.8 & 25 & - & 27.8 & 20 & 17 & 17.9 \\
\hline Degree \& Above & - & \begin{tabular}{|ll}
3 & 18.75 \\
\end{tabular} & - & - & - & 3 & 3.1 \\
\hline Total & 100 & $16 \quad 100$ & $25 \quad 100$ & 100 & 100 & 95 & 100 \\
\hline
\end{tabular}

Source: own survey; 2018. 


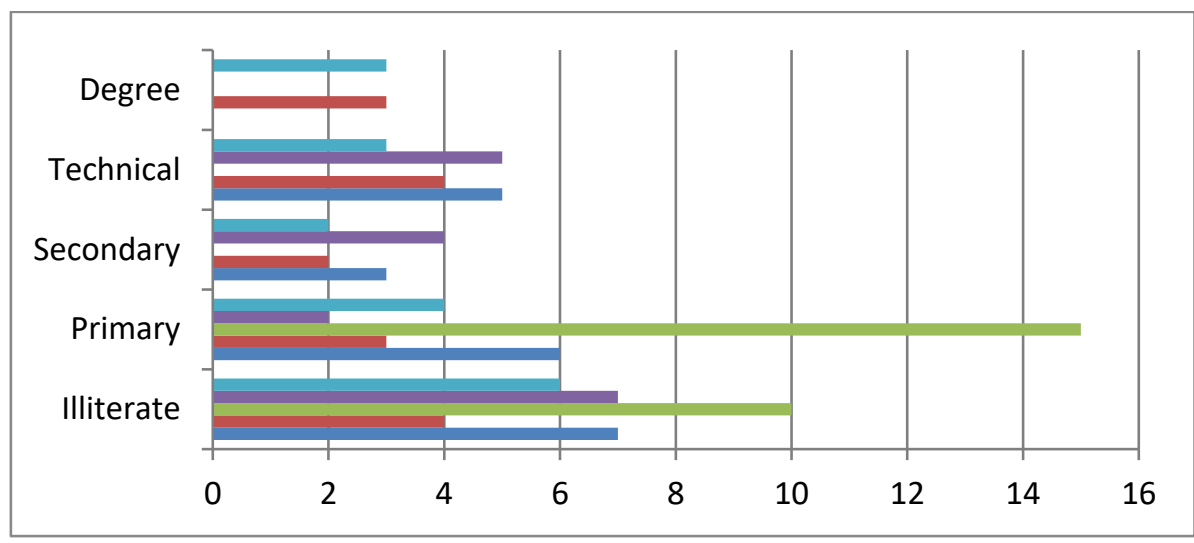

Figure 4. Educational levels of sample vendors and their activities

Source: own survey, 2018.

Education was one of the most important social aspects. The level of education influences productivity, in this cases the productivity of vendor activities is a key determinant factor of entrepreneurial activities. According to the table 4.4: about $35.8 \%$ are illiterates and $64.2 \%$ are literates. From the latter $31.6 \%$ have attended primary school education, $11.6 \%$ have attended secondary school, $17.9 \%$ are technical and vocational training and $3.1 \%$ have attended higher education.

Given this fact, one can observe that vending employments in study area were indeed substantial. This is the fact that vending activities played an important role in offering employment and income for broad masses of urban literates such as school leavers, school attendees, technical school and degree graduates and also for some illiterates.

\subsection{General socio economic Characteristics of the respondents}

There were many factors that force vendors to join walk occupation. The nature of side walk activities was one that causes people to operate on street. A piece of information on such kind of push and at the same time pull factors would offer the basis for decision making by government, local and foreign non-governmental organization and individuals to take positive actions in order to improve.

Table 5. Sample vendors by types of activities and their reason to join street vending activity

\begin{tabular}{|c|c|c|c|c|c|c|c|c|c|c|c|c|}
\hline \multirow[t]{2}{*}{ Reason Entry } & \multicolumn{2}{|c|}{$\begin{array}{c}\text { Fruit \& } \\
\text { Vegetables }\end{array}$} & \multicolumn{2}{|c|}{$\begin{array}{c}\text { Garments } \\
\text { vending }\end{array}$} & \multicolumn{2}{|c|}{ Motor services } & \multicolumn{2}{|c|}{ Food Vending } & \multicolumn{2}{|c|}{$\begin{array}{l}\text { Flowers } \\
\text { Vending }\end{array}$} & \multicolumn{2}{|c|}{ Total } \\
\hline & & $\%$ & $\mathrm{No}$ & $\%$ & No & $\%$ & $\mathrm{No}$ & $\%$ & No & $\%$ & No & $\%$ \\
\hline No option & 8 & 38.1 & 10 & 62.5 & 4 & 16 & 10 & 55.6 & 6 & 40 & 38 & 40 \\
\hline More Production & 8 & 38.1 & 6 & 37.5 & - & - & 8 & 44.4 & 4 & 26.7 & 26 & 27.4 \\
\hline Education & 5 & 23.8 & - & - & 21 & 84 & - & - & 5 & 33.3 & 31 & 32.6 \\
\hline Total & 21 & 100 & 16 & 100 & 25 & 100 & 18 & 100 & 15 & 100 & 95 & 100 \\
\hline
\end{tabular}

Source: own survey, 2018.

The situation of these street operators to exploit their future employment and income generating potential so as to alleviate the unlikely because of the growing urban poverty. As the above table 4.5 indicates $40 \%$ of the respondents are forced to enter street vending because of no optional jobs in other works, $27.4 \%$ more productive than other works and the remaining $32.6 \%$ use for educational purpose.

Table 6. Sample vendors by types of their business operation

\begin{tabular}{|l|c|c|}
\hline Types of firms & Frequency & Percentage \\
\hline Fruit and Vegetables & 21 & 26.3 \\
\hline Garment Vending & 16 & 16.8 \\
\hline Motor Services & 25 & 26.3 \\
\hline Food Vending & 18 & 18.9 \\
\hline Flowers Vending & 15 & 15.8 \\
\hline Total & 95 & 100 \\
\hline
\end{tabular}

Source: own survey, 2018. 
The following table shows the types of vendor's activities and their importance in terms of number of vendors employed and types of goods or services they sold or delivered to customers, individuals and households. Besides, vending activities are different in kind and Garments vending (clothes) and Flowers vending activities were by far predominant activities in the study area.

The informal sector was heterogeneous in character and comprises a wide variety of activities. There were even distinct differences among the vendor operations in terms of the major commodity or service groups sold or delivered and vendors' entrepreneurs in Mettu town also belonged to this group. They engaged in a variety of types of street based activities and offered different kinds of goods or service to the community at low cost.

Table 7 . The length of periods that sample vendors engage in their activity

\begin{tabular}{|c|c|c|c|c|c|c|c|c|c|c|c|c|}
\hline \multirow[t]{2}{*}{$\begin{array}{l}\text { Length of } \\
\text { Periods }\end{array}$} & \multicolumn{2}{|c|}{$\begin{array}{c}\text { Fruit \& } \\
\text { Vegetables }\end{array}$} & \multicolumn{2}{|c|}{$\begin{array}{c}\text { Garments } \\
\text { vending }\end{array}$} & \multicolumn{2}{|c|}{$\begin{array}{c}\text { Motor } \\
\text { Services }\end{array}$} & \multicolumn{2}{|c|}{ Food vending } & \multicolumn{2}{|c|}{ Flowers vending } & \multicolumn{2}{|c|}{ Total } \\
\hline & $\mathrm{No}$ & $\%$ & & $\%$ & & & $\mathrm{No}$ & $\%$ & No & $\%$ & No & $\%$ \\
\hline$<6$ Months & 8 & 38.1 & 3 & 18.75 & - & - & 10 & 55.6 & 6 & 40 & 27 & 28.4 \\
\hline 6 Months-2 Years & 5 & 23.8 & 6 & 37.5 & 15 & 60 & 2 & 11.1 & 4 & 26.7 & 32 & 33.7 \\
\hline 2-4 Years & 8 & 38.1 & 4 & 25 & 4 & 16 & - & - & 4 & 26.7 & 22 & 23.2 \\
\hline 4-8 Years & - & - & 3 & 18.75 & 6 & 24 & 2 & 11.1 & - & - & 9 & 9.4 \\
\hline$>8$ Years & - & - & - & - & - & - & 4 & 22.2 & 1 & 6.6 & 5 & 5.3 \\
\hline Total & 21 & 100 & 16 & 100 & 25 & 100 & 18 & 100 & 15 & 100 & 95 & 100 \\
\hline
\end{tabular}

Source: own survey, 2018.

As easily understand from the above table that the majority of the vendors were engaged in the activities for 6 months- 2 years $33.7 \%$ of the respondents, $23.2 \%$ of the respondents engaged for $2-4$ years, $28.4 \%$ of the respondents are for less than 6 months. 9.4\% of the respondents for $4-8$ years and only $5.3 \%$ of the respondents are for above 8 years.

From this we can take the conclusion that most of the respondents engaged in the activities for 6 months -2 years followed by 2-4 years. This indicates that most of the respondents engaged in the activity in recent years from 6 months -4 years by constituting about $72.5 \%$ from the respondents.

Table 8. Percentage of sample vendors by types of activities and ownership pattern

\begin{tabular}{|c|c|c|c|c|c|c|c|}
\hline \multirow[t]{2}{*}{ Ownership Pattern } & $\begin{array}{c}\text { Fruit \& } \\
\text { Vegetables }\end{array}$ & $\begin{array}{l}\text { Garment } \\
\text { Vending }\end{array}$ & $\begin{array}{c}\text { Motor } \\
\text { vending }\end{array}$ & Food vending & $\begin{array}{l}\text { Flowers } \\
\text { vending }\end{array}$ & \multicolumn{2}{|c|}{ Total } \\
\hline & No & No & No & No & No & No & $\%$ \\
\hline Sole Ownership & 1990.5 & $\begin{array}{ll}15 & 93.75 \\
\end{array}$ & 23 & $\begin{array}{ll}10 & 55.6\end{array}$ & 40 & 73 & 76.8 \\
\hline Family own & 9.5 & 6.25 & - & 44.4 & 26.7 & 15 & 15.8 \\
\hline Partnership & - & - & 28 & - & 33.3 & 7 & 7.4 \\
\hline Total & $21 \quad 100$ & 100 & $25 \quad 100$ & $18 \quad 100$ & 100 & 95 & 100 \\
\hline
\end{tabular}

Source: own survey, 2018.

The above table 8 exhibits that, dominant form of ownership in the street occupation was consistently individual proprietorship. Accordingly, about $76.8 \%$ almost exclusively, were organized under sole ownership. About $15.8 \%$ of vendors' establishment was family ownership while the remaining $7.4 \%$ was operated as partnership ownership. On other hand, there were some interesting inter-firm variations with respect to enterprise owners. In this study area $90.5 \%$ of total enterprise owners in Fruits and Vegetables, 93.75\% in Garments vending (clothes), $92 \%$ in Motors service, $40 \%$ in Flowers vending activities and $55.6 \%$ in food vending were owned individually.

Table 9. sample vendors by type's activities and ways of running their business activities

\begin{tabular}{|c|c|c|c|c|c|c|c|c|c|c|}
\hline \multirow[t]{2}{*}{$\begin{array}{c}\text { Ways of Running Their } \\
\text { business }\end{array}$} & $\begin{array}{c}\text { Fruit \& } \\
\text { Vegetables }\end{array}$ & $\begin{array}{l}\text { Garment } \\
\text { Vending }\end{array}$ & \multicolumn{2}{|c|}{$\begin{array}{c}\text { Motor } \\
\text { vending }\end{array}$} & \multicolumn{2}{|c|}{ Food vending } & \multicolumn{2}{|c|}{$\begin{array}{l}\text { Flowers } \\
\text { vending }\end{array}$} & \multicolumn{2}{|c|}{ Total } \\
\hline & No $\%$ & No $\%$ & & & $\mathrm{No}$ & $\%$ & & & $\mathrm{Nc}$ & $\%$ \\
\hline Self employed & $10 \quad 47.6$ & 50 & 15 & 60 & 16 & 88.8 & 10 & 66.7 & 59 & 62.1 \\
\hline Un paid family workers & 52.4 & 50 & - & - & 2 & 11.2 & 5 & 33.3 & 26 & 27.4 \\
\hline Employed workers & 1) & 2) & 10 & 40 & 3) & - & 4) & - & 10 & 10.5 \\
\hline Total & 100 & 100 & 25 & 100 & 18 & 100 & 15 & 100 & 95 & 100 \\
\hline
\end{tabular}

Source: own survey, 2018. 
The above table indicates that $62.1 \%$ of the sample vendors running their business through self-employed $27.4 \%$ through unpaid family worker and only $10,5 \%$ run their business through employed workers. The reason behind that of the domination self-employed this activity is owners were states their relationships with their business operations. Thus, employment in the street occupation in study area held working self-employed, unpaid family workers and some paid employees. Clearly, in the vendor context, street activities represent mainly survival strategies adopted in face of growing unemployment. The evidence seems to support the widely held view that the majority of the urban labour force is self-employed.

Table 10. Sample vendors by types of activities and level of their initial capital

\begin{tabular}{|c|c|c|c|c|c|c|c|c|c|c|c|c|}
\hline \multirow[t]{2}{*}{$\begin{array}{l}\text { Initial capital in } \\
\text { birr }\end{array}$} & \multicolumn{2}{|c|}{$\begin{array}{c}\text { Fruit \& } \\
\text { Vegetables }\end{array}$} & \multicolumn{2}{|c|}{$\begin{array}{c}\text { Garments } \\
\text { vending }\end{array}$} & \multicolumn{2}{|c|}{ Motor services } & \multicolumn{2}{|c|}{ Food vending } & \multicolumn{2}{|c|}{ Flowers vending } & \multicolumn{2}{|r|}{ Total } \\
\hline & $\mathrm{No}$ & $\%$ & No & $\%$ & No & $\%$ & No & $\%$ & No & $\%$ & No & $\%$ \\
\hline$<100$ & & 52.4 & - & - & - & - & 4 & 22.2 & 3 & 20 & 18 & 18.9 \\
\hline $101-250$ & 4 & 19 & 4 & 25 & - & - & 4 & 22.2 & 3 & 20 & 5 & 15.8 \\
\hline $251-500$ & 3 & 14.3 & - & - & - & - & 3 & 16.7 & 3 & 20 & 9 & 9.5 \\
\hline 501-1000 & 3 & 14.3 & 6 & 37.5 & - & - & - & - & 3 & 20 & 12 & 12.6 \\
\hline $1001-2000$ & - & - & 3 & 18.75 & 10 & 40 & 2 & 11.2 & 2 & 13.3 & 17 & 17.9 \\
\hline $2001-10000$ & - & - & 3 & 18.75 & 15 & 60 & 5 & 27.8 & 1 & 6.7 & 24 & 25.3 \\
\hline Total & 21 & 100 & 16 & 100 & 25 & 100 & 18 & 100 & 15 & 100 & 95 & 100 \\
\hline
\end{tabular}

Source: own survey, 2018.

As explained in the above table 10 about $18.9 \%$ of vendor entrepreneurs stated with initial capital of hundred birr and below, whereas, $15.8 \%, 9.5 \% 12.6 \%, 17.9 \%$ and the remaining $25.3 \%$ started the business with initial capital between 101-250 birr, 251-500 birr, 501-1000 birr, 1001-2000 birr and of the birr 2000 and above respectively. The low level of initial capital requirements is the absence of reliable source of finance. The level of initial capital is different among vending activities. For example, about $85.7 \%$ of Fruit and Vegetables owners began their operation with total of birr 500 and below, followed by Garment vending (food) constitutes about $61.1 \%$. The initial capital requirement in the street vending activity was observed to vary with the types of vendor's activities but it is generally minimal.

Table 11. Sample vendors by types of activities and their present capital

\begin{tabular}{|c|c|c|c|c|c|c|c|c|c|c|c|}
\hline \multirow[t]{2}{*}{ Current capital in birr } & \multicolumn{2}{|c|}{$\begin{array}{c}\text { Fruit \& } \\
\text { Vegetables }\end{array}$} & \multicolumn{2}{|c|}{$\begin{array}{c}\text { Garments } \\
\text { vending }\end{array}$} & \multicolumn{2}{|c|}{$\begin{array}{c}\text { Motor } \\
\text { services }\end{array}$} & \multicolumn{2}{|c|}{$\begin{array}{c}\text { Food } \\
\text { vending }\end{array}$} & \multicolumn{2}{|c|}{$\begin{array}{l}\text { Flowers } \\
\text { vending }\end{array}$} & Total \\
\hline & & $\%$ & No & $\%$ & & $\%$ & & $\%$ & & $\%$ & No $\%$ \\
\hline$<100$ & - & - & - & - & - & - & 1 & 5.6 & - & - & $1 \quad 1.05$ \\
\hline $100-500$ & 20 & 95.2 & - & - & - & - & 8 & 44.4 & 5 & 33.3 & $33 \quad 34.74$ \\
\hline $501-1500$ & 1 & 4.8 & 10 & 62.5 & 10 & 40 & & 44.4 & 5 & 33.3 & $\begin{array}{ll}34 & 35.8\end{array}$ \\
\hline $1501-2000$ & - & - & - & - & 5 & 20 & & - & 3 & 20 & 8.42 \\
\hline $2001-10000$ & - & - & 3 & 18.75 & 10 & 40 & 1 & 5.6 & 1 & 6.7 & $\begin{array}{ll}15 & 15.8 \\
\end{array}$ \\
\hline$>10000$ & - & - & 3 & 18.75 & - & - & - & - & 1 & 6.7 & 4.2 \\
\hline Total & 21 & 100 & 16 & 100 & 25 & 100 & 18 & 100 & 15 & 100 & $\begin{array}{ll}95 & 100 \\
\end{array}$ \\
\hline
\end{tabular}

Source: own survey, 2018.

The above table 11 shows that out of 95 respondents, $1.05 \%$ had current capital of birr 100And below, $34.74 \%$ between birr 100-500, 35.8\% between birr 501-1500, 8.42\% between birr1501-2000, 4.2\%between birr 200010,000 , and the remaining $10.5 \%$ would have a capital of Birr 10,000 and above. The general picture of this survey reveals that there is an improvement of Venders' income/current capital over that of the level of initial capital. ome street venders have shifted their capital from lower to higher level. For instance, there are no venders who had initial Capital greater than birr 10,000. But about 10.5\%from sampled vendors had more than birr 10,000 of current capital.

Table 12. Tthe monthly income of the sample venders from their activities

\begin{tabular}{|c|c|c|c|c|c|c|c|c|c|c|c|c|}
\hline \multirow[t]{2}{*}{$\begin{array}{l}\text { Monthly } \\
\text { Income }\end{array}$} & \multicolumn{2}{|c|}{$\begin{array}{c}\text { Fruit \& } \\
\text { Vegetables }\end{array}$} & \multicolumn{2}{|c|}{$\begin{array}{c}\text { Garments } \\
\text { vending }\end{array}$} & \multicolumn{2}{|c|}{$\begin{array}{c}\text { Motor } \\
\text { services }\end{array}$} & \multicolumn{2}{|c|}{ Food vending } & \multicolumn{2}{|c|}{$\begin{array}{l}\text { Flowers } \\
\text { vending }\end{array}$} & \multicolumn{2}{|c|}{ Total } \\
\hline & No & $\%$ & & $\%$ & & $\%$ & No & $\%$ & No & $\%$ & No & $\%$ \\
\hline$<100$ & - & - & - & - & - & - & 2 & 11.1 & - & - & 2 & 2.1 \\
\hline $101-250$ & 4 & 19.05 & - & - & - & - & 2 & 11.1 & 4 & 26.7 & 10 & 10.5 \\
\hline $251-500$ & 6 & 28.6 & 4 & 25 & 15 & 60 & 6 & 33.4 & 3 & 20 & 34 & 35.8 \\
\hline $501-1000$ & 7 & 33.3 & 6 & 37.5 & 5 & 20 & 4 & 22.2 & 3 & 20 & 25 & 26.3 \\
\hline$>10000$ & 4 & 19.05 & & 37.5 & 5 & 20 & 4 & 22.2 & 5 & 33.3 & 24 & 25.3 \\
\hline Total & 21 & 100 & 16 & 100 & 25 & 100 & 18 & 100 & 15 & 100 & 95 & 100 \\
\hline
\end{tabular}

Source: own survey, 2018. 
Table 12 reveals vendors respondents net income report on street vending industries. Accordingly, on average month only $2.1 \%$ of vendors reportedly earned 100 and below, $10.5 \%$ from 100-250 birr, 35.8\% from 250 500 birr, $26.3 \%$ from 500-1000 and $25.3 \%$ of vendor entrepreneurs would earn birr, 1000 and above. Thus, vendors in the last income groups are relatively benefited worth on average monthly than other groups income of vendors.

The probable reason is that they had better initial capital and work by high capital, they supply highly demanded products, access to supplies of market input and market output than other vendor enterprises. The result from the above table also shows that the relationship between monthly income and types activities far different activities. This indicates that vendors who sell second hand clothes earn mostly more income about $37.5 \%$ among respondents earn more than birr 1000 and above followed by miscellaneous activities such as merchants, electronic materials and other products accounting for about $20 \%$ of all respondents.

Table 13. Sample vendors by types of activities and purpose of using income generating from the activity

\begin{tabular}{|c|c|c|c|c|c|c|c|c|c|}
\hline \multirow[t]{2}{*}{ Purpose of income } & $\begin{array}{c}\text { Fruit \& } \\
\text { Vegetables }\end{array}$ & $\begin{array}{l}\text { Garments } \\
\text { vending }\end{array}$ & $\begin{array}{c}\text { Motor } \\
\text { services }\end{array}$ & \multicolumn{2}{|c|}{$\begin{array}{c}\text { Food } \\
\text { vending }\end{array}$} & \multicolumn{2}{|c|}{$\begin{array}{l}\text { Flowers } \\
\text { vending }\end{array}$} & \multicolumn{2}{|c|}{ Total } \\
\hline & No $\%$ & No & No $\%$ & No & $\%$ & & & $\mathrm{No}$ & $\%$ \\
\hline Family Consumption & $\begin{array}{ll}5 & 23.8 \\
\end{array}$ & 25 & 20 & 4 & 22.2 & 1 & 6.7 & 19 & 20 \\
\hline Finance during emergency & $-\quad-$ & - & - & - & - & 3 & 20 & 3 & 3.1 \\
\hline To start other business & $\begin{array}{ll}5 & 23.8\end{array}$ & 37.5 & 20 & 4 & 22.2 & 3 & 20 & 23 & 24.2 \\
\hline Help family members & - & $\begin{array}{ll}3 & 18.75 \\
\end{array}$ & 10 & 10 & 55.6 & 3 & 20 & 26 & 27.4 \\
\hline Other (education) & $\begin{array}{ll}11 & 52.4\end{array}$ & $\begin{array}{ll}3 & 18.75\end{array}$ & 20 & $>$ & - & 5 & 33.3 & 24 & 25.3 \\
\hline Total & $21 \quad 100$ & $16 \quad 100$ & 100 & 18 & 100 & 15 & 100 & 95 & 100 \\
\hline
\end{tabular}

Source: own survey, 2018.

As one can see from table 13 above $20 \%$ of the sample respondent are using the income generating from the activity for family consumption followed by those who uses to start other business accounting for $24.2 \%$ of all respondents.

Others, for example, $25,3 \%$ of the respondents spend their income on educational purpose, whereas, $27.4 \%$ uses to help family members and only $20 \%$ use to finance during emergency.

Table 14. Sample vendors by types activities and changes in vendors livelihood over time

\begin{tabular}{|c|c|c|c|c|c|c|c|c|c|}
\hline \multirow{2}{*}{$\begin{array}{c}\text { Is your Income } \\
\text { Change over } \\
\text { time? }\end{array}$} & $\begin{array}{c}\text { Fruit \& } \\
\text { Vegetables }\end{array}$ & $\begin{array}{c}\text { Garments } \\
\text { vending }\end{array}$ & Motor services & \multicolumn{2}{|c|}{ Food vending } & \multicolumn{2}{|c|}{$\begin{array}{l}\text { Flowers } \\
\text { vending }\end{array}$} & \multicolumn{2}{|c|}{ Total } \\
\hline & No & No & No & No & $\%$ & $\mathrm{Nc}$ & $\%$ & $\mathrm{No}$ & $\%$ \\
\hline Yes & 95.2 & $\begin{array}{ll}10 & 62.5 \\
\end{array}$ & 60 & 14 & 77.8 & 10 & 66.7 & 69 & 72.6 \\
\hline No & 4.8 & 37.5 & 40 & 4 & 22.2 & 5 & 33.3 & 26 & 27.4 \\
\hline Total & 100 & 100 & 100 & 18 & 100 & 15 & 100 & 95 & 100 \\
\hline
\end{tabular}

Source: own survey, 2018.

The above table 14 indicates that majority of the vendors about $72.6 \%$ were realized change in livelihood time while the remaining $27.4 \%$ did not realized change in their livelihood. Generally, the above table shows that the income of street vendors change from time to time.

Table 15. The major challenges of sample vendors business

\begin{tabular}{|c|c|c|c|c|c|c|c|c|c|c|}
\hline \multirow[t]{2}{*}{ Problem faced } & $\begin{array}{c}\text { Fruit \& } \\
\text { Vegetables }\end{array}$ & $\begin{array}{c}\text { Garments } \\
\text { vending }\end{array}$ & \multicolumn{2}{|c|}{$\begin{array}{c}\text { Motor } \\
\text { services }\end{array}$} & \multicolumn{2}{|c|}{ Food vending } & \multicolumn{2}{|c|}{$\begin{array}{l}\text { Flowers } \\
\text { vending }\end{array}$} & \multicolumn{2}{|c|}{ Total } \\
\hline & No $\%$ & No & $\mathrm{No}$ & $\%$ & No & $\%$ & & $\%$ & No & $\%$ \\
\hline $\begin{array}{l}\text { Government } \\
\text { Restriction }\end{array}$ & $\begin{array}{ll}5 & 23.8\end{array}$ & $\begin{array}{ll}3 & 18.75\end{array}$ & 15 & 60 & & 55.6 & 3 & 20 & 36 & 37.9 \\
\hline Burning sun & $\begin{array}{ll}6 & 28.6 \\
\end{array}$ & 6.25 & - & - & 5 & 27.8 & 3 & 20 & 15 & 15.8 \\
\hline Rain & $\begin{array}{ll}5 & 23.8 \\
\end{array}$ & 25 & 5 & 20 & 3 & 16.6 & 2 & 13.3 & 19 & 20 \\
\hline Theft & $\begin{array}{ll}5 & 23.8 \\
\end{array}$ & $\begin{array}{ll}3 & 18.75 \\
\end{array}$ & - & - & - & - & 2 & 13.3 & 10 & 10.5 \\
\hline Other & $>$ & $\begin{array}{ll}5 & 31.25 \\
\end{array}$ & 5 & 20 & - & - & 5 & 33.4 & 15 & 15.8 \\
\hline Total & $21 \quad 100$ & $16 \quad 100$ & 25 & 100 & 18 & 100 & 15 & 100 & 95 & 100 \\
\hline
\end{tabular}

Source: own survey, 2018. 
As reported in table 15 above that about $37.9 \%$ faces problem of government restriction, $15.8 \%$ rain during summer and other rainy season, $20 \%$ burning sun during winter and other $15.8 \%$ faces other problems such as inadequate capital to choose the type of activities.

Lack of government support is among obstacle hindering the growth of vendor's business turnover. The sampled vendors reported that government is not support their activities; even restrict their activities and sometimes penalize the vendors. In addition, vendors lacked access to institution, legally approved site and government facilities for loans. Then, they expect from government to fulfill the above facilities.

\subsection{Government attitudes and polices towards the street vendors'}

Street vending is an ancient and important occupation found in virtually every country and major city around the world. Street vendors add Vitality to the streets-cape and contribute to economic activity and service provision, but many observers also associate them with congestion, health and safety risks, tax evasion and the sale of shoddy merchandise.Numerous national laws, local laws and municipal ordinances apply to street vending or are specifically targeted at street vendors, and most countries have a long history of regulating their activity.

A key feature of this paper was that it focuses directly on street vendors as an occupational group, rather than treating them as an example of some larger aggregate group such as the informal sector, petty commodity production, underemployment, micro-enterprises, retailing, the service sector, or the underground economy.Street vending was simply the retail or wholesale trading of goods and services in streets and other related public axes such as alleyways, avenues and boulevards.

No attempt is made to judge whether street vending should be placed in a larger category, and if so, in what category it should be placed. Each of the larger categories mentioned carries a considerable weight of intellectual and ideological motors and its use may obscure.

\subsection{Conclusion and Recommendition}

\subsection{Conclusion}

This section draws conclusion about the study on the assessing status and the role of street vending in urban livelihood in Mettu towns.

The study was identified different types of vendor activities. These were sellers of fruits and vegetables, Garment Vending (clothes), Motors Services, food vending and provides of Flowers Vending activities. These street enterprises provide some advantages to the town's economy and population by performing major role in the sale and distribution of commodities or in delivering urban services. Garment Vending or clothes and Flowers Vending activities are found to be the predominant activities. The survey reveals that the majority of street vendors counting $45.3 \%$ were concentrated in the young age group between 18-40 years. This age group is fund to be either married or preparing to marry to set up own family apart from parents stock. Thus, street vending would be an attractive alternative to these youths than waiting for employment in urban modern sector units, which are at best in very limited, short in supply and highly educated and skilled based persons than they are. Thus, the street vending was the important source of employment and income for both sexes. Males group represent the higher portion in the survey.

The reasons for growing of informal sector in anywhere in the includes weak education system. That is incapable for training the students for acquiring a potential rewarding job, irrespective of the growth of a nay nation and advancement in the economic development of any country. Informal sector was happily absorbing one who want to join the sector. Both the sex that is male and female getting involved in informal sector of employment and are trying to earn their livelihood through it. In Mettu town men and women were active participant in the informal sector, yet women are still considered as the most vulnerable sex out of the two in the business. Family responsibilities such as child care, education and marriage keeps on forcing them deep in to the sector. This shows that males are some likely adopted to participate in such activities in which it may require standing aside of difficult work activities such as complex weather condition social disturbance and the like. It is also found that street vending is a particularly important source of employment and income for single, married, divorced and widowed. The single group represents the proportion than married, divorced and widowed. This implies that vendor's activities represent mainly survival strategies adopted in the face of growing unemployment and under employment aiming at raising incomes for own support so as to alleviate 
hunger and poverty. This fact further shows the effort vendors are making to support them and to strengthen their economic base and stock before marriage.

The result also showed that the street vending activity sector was better in the improvement of vendor's income / current capital over that of the level of initial capital. However, the level of capital in vendor business is minimal as the whole. From this we can conclude that most of the street vendors are obtaining generating income from the activity even not able to fulfill their basic needs.

The study found that the majority of the street vendors face the problem of government restriction $37.9 \%$ followed by burning sun $15.8 \%$, rain $20 \%$, theft 10.5 and others 15.8 . the informal sectors from past is facing the problems related to the policy development specific to those involving informal sector. Almost handfuls of laws not effective exists for those involving in informal sector. The laws that are there only deals with the rights that are well addressable through human rights and are not specific to business purpose activities.

The unavailability of labor statistics in some countries make it more difficult to address the cause or absence of business policies related to the informal sector. If there is proper documentation of contribution of informal sector in the social economic development that includes income and education status of those indulging in informal, then the policy making will be more effective and then will be more focused upon the specific business pain points that are being experienced at present by the people involved in informal sector.

This implies that luck of government support was among the obstacle hindering the growth of vendors business. Nearly all vendors operate in open air or on sidewalks. About $37.9 \%$ of vendor's entrepreneurs run their business from open rain displaying their goods or services on pavements having no shade against rain or sunshine. The most absorption of the work force in any country occurs in the informal sectors only. The informal activities include working in food joints, street vending and merchandising etc. Stringent regulations for starting business in the country, impotent work laws and other environmental factors force the growing population to adopted informal sector as a source of livelihood.

In Mettu town informal sector has its deep root and many still considers the sector the sector as the best alternative to earn livelihood if all means fails. Both male and female of age even less than is actively involving the sector. The reason behind involvement of large population in the sector being the monetary return factor. The informal sector has the potential to start giving output from day one of the investment.

The informal sector units operates as an organization with no division of capital and labor, every agency working towards proper labor laws is working to define the informal sector of Mettu town. These organizations define informal sector as those areas of business or employments that are being held by individual and household and not legally constituted or incorporated. The business never has a fixed business size neither the size of employee structure is documented the organization will $\mathrm{n}$ ever noticed professional hiring or firing. In case of domestic help the worker is a non - contracted in the house he or she is working in and is supposed to have complete liberty of turning up or not for the any or many days.

The informal sectors from past is facing the problems related to the policy development specific to those involving informal sector. Almost handfuls of laws not effective exists for those involving in informal sector. The laws that are there only deals with the rights that are well addressable through human rights and are not specific to business purpose activities. The unavailability of labor statistics in some countries make it more difficult to address the cause or absence of business policies related to the informal sector. If there was proper documentation of contribution of informal sector in the social economic development that includes income and education status of those indulging in informal, then the policy making will be more effective and then will be more focused upon the specific business pain points that are being experienced at present by the people involved in informal sector.

A separate department was almost the need of the day that can handle the informal sector and functioning related to the same. The department can handle the proposed survey and could actually mine the obtained data and extract necessary information from the data and use it for specific reasons, like for to account for the contribution of informal sector for the society and on the national economy level once the data will be well at hand and information starts to come out from the process of data mining the policy makers will be able to decide the revenue obtained to the government through informal sector and will be able to plan the next allotment from the budget for progressive development. 
The government will be able to focus upon fixing the wages for domestic help and rolling out targeted subsidies for the informal sector employees with targeted specific policies the government can change the scenario of informal sector for good and can introduce new economic policies that actually suits the need of the informal workers by protecting their needs and acting as a virtual guardian for their business.

\subsection{Recommendations}

The study has identified convinced challenges that are related to the street vendors and their activities. It has suggested solutions to the identified problems that can have a long term nature requiring both action programs and research. Accordingly study makes the following recommendation:

\section{Based on the findings the recommendations are:}

The following recommendations are be made based on the findings

$>$ The government should come forward to crate and enforce legislation for the street vending practices, their conditions.

$>\quad$ The formation of a vending federation supporting vending activities in informal sector is the need of the time.

$>\quad$ The women involved in the informal sector should be encouraged to join the self-help group.

$>\quad$ The vending activities should be effectively monitored by the ward members and should stand for the vendors if they are right and their rights are encroached by an organization.

Municipal Corporation should be responsible for properly managing the informal sector in the cities and should provide formal vending regions to the people involved in the street vending so as that the street vendors to do not create disorganization of the streets.

$>\quad$ Actions should be immediately taken on the street vendors that are not following the rules and regulation laid by the municipal corporation.

$>\quad$ The government should run skill development programs for the vendors.

$>\quad$ The vendors should be encouraged to join the VTP skill program run by the state and the central government.

$>\quad$ Laws should be formulated on the priority basis to fix the wages of the worker working in the informal sector.

$>\quad$ Specialized micro financial units should be formed to support the street vendors.

$>\quad$ Free night schools are necessary for educating the street vendors.

List of Abbreviations

CSA Central Statistical Authority

GDP Gross Domestic Product

IEMS Informal Economy Monitoring Study

ILO International Labor Organization

JASPA Jobs and Skills Program for Africa

LDCs Least Developing Countries

MUPA Missouri University Postdoctoral Association

\section{References}

1. Bromley, Rosemary D. F. (1998). Informal Sector Commerce: Expansion and Exclusion in the Historic Centre of the Latin American City. DOI: https://doi.org/10.1111/1468-2427.00138

2. Bhowmik, Sharit K. (2000). Improving Regulatory Framework for Income Enhancement of the Urban Livelihood: Study of Delih (India) for UNHABITAT, Nairobi. https://www.jstor.org/stable/4416705?seq=1

3. Bhowmik, Sharit K. (2012). Street Vendors in the global urban economy. Abingdon, United Kingdom, Taylor and Francis. http://www.gbv.de/dms/zbw/61573135X.pdf 
4. Boyer, M. Christine (1992). Cities for Sale: Merchandising History at South Street Sea port, pp. 181-204, in Variations on a Theme Park: The New American City and the End of Public Space, edited by Michael Sorkin. New York: Hill and Wang, Noonday Press. DOI: https://doi.org/10.1007/978-1-4615-0659-1 7

5. Cross, John C. (1998). Informal Politics: Street Vendors and the State in Mexico City. Stanford: Stanford University Press. DOI: https://doi.org/10.1017/s0022216x02476341

6. Central Statistical Authority (2004a). Urban biannual employment unemployment Survey. Statistical Bulletin, vol. 319, Addis Ababa. http://www.csa.gov.et/ehioinfo-internal?download=921:key-findings2018-ueus\&start=15

7. Central Statistical Authority. (2004b). Report on large and medium scale Manufacturing and electricity industrial survey. Statistical Bulletin, volume 321, Addis Ababa. http://www.csa.gov.et/priceindices/consumer-price-index/category/14-all-survey-reports?download=730:large-scale-2007

8. De Soto, H. (1989). The other past, Harder and Exploring the frontier of livelihood research row. New York. https://core.ac.uk/download/pdf/80724306.pdf

9. De Soto, Hernando (1992b). Linkage, Heterogeneity and Income Determinants in Petty Street Trading: The Case of Calcutta. World Development, 20, 1143-1161. https://ideas.repec.org/a/eee/wdevel/v20y1992i10p1443-1461.html

10. Drescher, A.W. (1997). Urban Agriculture In The Seasonal Tropics Of Central Southern Africa. A Case Study of Lusaka/Zambia, Urban Agriculture Notes, http://www.cityfarmer.org/axelB.html.

11. Frayne, B. (2005). Survival of the Poorest: Migration and Food Security in Namibia. In AGROPOLIS : The Social, Political, and Environmental Dimensions of Urban Agriculture, edited by L. Mougeot: Earthscan/IDRC. https://www.idrc.ca/sites/default/files/openebooks/186-8/index.html

12. Jones, Gareth A., and Ann Varley (1994). The Contest for the City Centre: Street TradersVersus Buildings. Bulletin of Latin American Research, 13, 27-44. DOI: 10.2307/3338699.

13. John Gaber (1994). Manhattan's 14th Street Vendors' Market: Informal Street Peddlers' Complementary Relationship with NewYork City's Economy. Urban Anthropology, 23, 373-408, New York. https://www.jstor.org/stable/40553272

14. Kusakabe, K. (2006). Policy Issues on Street Vending: An Overview of Studies in Thailand, Cambodia and Mongolia Bangkok, International Labour Office. https://www.ilo.org/wcmsp5/groups/public/---asia/--ro-bangkok/documents/publication/wcms bk pb 119 en.pdf

15. Mbiba, Beacon (1995). Urban agriculture in Zimbabwe: implications for urban management, urban economy, the environment, poverty and gender. Aldershot: Avebury, McCaskie. https://www.worldcat.org/title/urban-agriculture-in-zimbabwe-implications-for-urban-management-andpoverty/oclc/33284921

16. McGee, T. G. and Yeung, Y. M. (1977). Hawkers in Southeast AsianCities: Planning for the Bazaar Economy. Ottawa: International Development Research Centre, Lodon. DOI: https://doi.org/10.2307/2053487

17. Mlozi, M., Sofer, M. and Foeken, D. (2003). Sustainable urban agriculture in Tanzania: A study of two towns, Research report for Netherlands-Israel development Research Programme (NIRP). https://openaccess.leidenuniv.nl/bitstream/handle/1887/4678/ASC-1241504-003.pdf?sequence=1

18. Omary, A.(2002). Nutritional hygienic and socio economic dimensions of street vendors in urban areas; the case of Nairobi. https://library.wur.nl/WebQuery/wda/1641411

19. Owuor, S.O. (2006). Bridging the urban-rural divide: multi-spatial livelihoods in Nakuru town, Kenya. Research Report 81. Leiden: African Studies Centre. https://profiles.uonbi.ac.ke/samowuor/files/sam owuor uon website.pdf

20. Potts, D. (1997). Urban lives: adopting new strategies and adapting rural links, in Rakodi, Carole (ed), The Urban Challenge in Africa: Growth and Management of its Large Cities, Tokyo: United Nations University Press. http://archive.unu.edu/unupress/unupbooks/uu26ue/uu26ue00.htm

21. Sethuraman (1981). The role of urban informal sector in Sethuraman (ed.); the urban informal sector in developing countries. Employment, poverty, and Environmental. International Labor Organization, Geneva. https://www.jstor.org/stable/43157620?seq=1

22. Tambwe, N., M. Rudolph, and R. Greenstein (2011). Instead of begging I farm to feed my children': urban agriculture - an alternative to copper and cobalt in Lubumbashi. Africa, 81 (3), 391-412. DOI: https://doi.org/10.1017/S000197201100043X

23. Todaro, P.M. (1976). Economic development in the third world. An introduction to problems and policies in an global perspective. London, New York. 
https://mediasrv.aua.gr/eclass/modules/document/file.php/AOA215/Economic\%20Development\%20\%20Todaro\%20and\%20Smith.pdf

24. UN Habitat (2008). The state of African cities: A framework for addressing urban challenges in Africa. United Nations Human Settlements Programme. https://repository.uneca.org/handle/10855/15223

25. World Bank (1991). The effects of education on health. World Bank staff working Paper 405. http://documents.worldbank.org/curated/en/148951468764703628/The-effects-of-education-on-health 